DOI 10.14746/ssp.2021.1.2

Rafał KAMPROwSKI

Uniwersytet im. Adama Mickiewicza w Poznaniu

ORCID ID: 0000-0002-9610-4394

\title{
Polityka energetyczna w programach największych polskich partii politycznych w wyborach parlamentarnych w 2019 roku
}

Streszczenie: Przedmiotem badań niniejszego artykułu jest wizja kreowania polityki energetycznej obecna w programach politycznych największych polskich partii politycznych w 2019 roku. Należy podkreślić, iż głównym jej celem jest zapewnienie bezpieczeństwa energetycznego. Celami podjętych przez autora badań jest wskazanie, omówienie i porównanie koncepcji zapewnienia Polsce bezpieczeństwa energetycznego w przypadku wygrania wyborów parlamentarnych. Do osiągnięcia tak określonych celów badań posłużyły następujące problemy badawcze: w jakim zakresie zapewnienie Polsce bezpieczeństwa energetycznego jest obecne w analizowanych programach politycznych? Poprzez jakie narzędzia największe partie polityczne w Polsce kreowały energetyczny wymiar bezpieczeństwa? Jakie główne trudności w zapewnieniu bezpieczeństwa energetycznego Polski uwypuklają badane partie polityczne? Czy istnieje zbieżność partii politycznych w wizji zagwarantowania Polsce bezpieczeństwa energetycznego? W poniższym artykule posłużono się następującymi metodami badawczymi: porównawczą oraz analizy źródeł. Zastosowano również technikę analizy treści.

Słowa kluczowe: bezpieczeństwo; bezpieczeństwo energetyczne; programy polityczne; partie polityczne

\section{Wprowadzenie}

Wybory parlamentarne odbyły się w Polsce 13 października 2019 roku. Zakończyły się one zwycięstwem Prawa i Sprawiedliwości, które uzyskało 43,59\% głosów przekładających się na 235 mandatów w Sejmie (Państwowa Komisja Wyborcza, 2019). Największa partia opozycyjna - Koalicja Obywatelska - uzyskała 27,40\% głosów i 134 mandaty. W wyniku przeprowadzonych wyborów, do Sejmu powrócił po czterech latach Sojusz Lewicy Demokratycznej. Sukces odniosła także Konfederacja Wolność i Niepodległość. Partie te uzyskały odpowiednio 
49 i 11 mandatów. Polskie Stronnictwo Ludowe, będąc partią o jednym z najdłuższych staży sejmowych odnotowało wynik 8,55\%, co przełożyło się na 30 mandatów poselskich (Państwowa Komisja Wyborcza, 2019). W Sejmie RP zasiadli więc przedstawiciele partii postrzeganych jako „prawicowe” tudzież „,konserwatywne”, ,centrowe” - „ludowe” jak i ,liberalne” oraz „lewicowe”. Bezpieczeństwo energetyczne państwa, podobnie do kampanii parlamentarnej z 2015 roku, było akcentowane przez polityków największych partii politycznych w 2019 roku. Problematyka ta dostrzegana była również przez opinię społeczną. Zgodnie z poglądem ankietowanych w badaniu IBRiS dla „Rzeczpospolitej” tematy, które powinny być ważne w czasie kampanii to: poprawa służby zdrowia (78\%), ochrona klimatu (64\%), walka z drożejącą żywnością (57\%) oraz reforma sytemu edukacji (53\%) (Kolanko, 2019). Wskazana ochrona klimatu wiąże się pośrednio z energetycznym aspektem bezpieczeństwa, choćby w kontekście przejścia na tzw. odnawialne źródła energii czy ograniczenie emisji dwutlenku węgla do atmosfery. Jak podaje również Centrum Badania Opinii Społecznej problematyka bezpieczeństwa dostępu do energii zajmuje jedno z czołowych miejsc. Polacy obawiają się najbardziej podwyżek cen energii elektrycznej - 63,6\% ankietowanych. Obecna i przyszłe kadencje parlamentu będą musiały, w koherentny i czytelny dla wyborców sposób, zająć się tą tematyką (The Warsaw Institute Review, 2019). Przedmiotem badań niniejszego artykułu jest wizja kreowania polityki energetycznej obecna $\mathrm{w}$ programach politycznych największych polskich partii politycznych w 2019 roku. Ujęta w temacie artykułu polityka energetyczna jest przez autora rozumiana przez pryzmat jej głównego celu, jakim jest zapewnienie bezpieczeństwa energetycznego. Wyraźnie wskazuje to opracowana przez Ministra Energii „Polityka energetyczna Polski do 2040 roku”. Celami podjętych przez autora badań jest wskazanie, omówienie i porównanie koncepcji zapewnienia Polsce bezpieczeństwa energetycznego w przypadku wygrania wyborów parlamentarnych. Do osiągnięcia tak określonych celów badań posłużyły następujące problemy badawcze: $\mathrm{w}$ jakim zakresie zapewnienie Polsce bezpieczeństwa energetycznego jest obecne w analizowanych programach politycznych? Poprzez jakie narzędzia największe partie polityczne w Polsce kreowały energetyczny wymiar bezpieczeństwa? Jakie główne trudności w zapewnieniu bezpieczeństwa energetycznego Polski uwypuklają badane partie polityczne? Czy istnieje zbieżność partii politycznych w wizji zagwarantowania Polsce bezpieczeństwa energetycznego? Poprzez programy polityczne partie sytuują się w konkretnej przestrzeni historycznej i ideowej 
stając się tym samym autodefinicją partii jako zbiorowego aktora na scenie politycznej (Woźniak, 2017, s. 42). Jak słusznie zauważył Marek Tyrała dokument ten to także zbiór celów i zamierzeń formułowanych przez grupy, których celem jest zdobycie władzy. Stanowi on pewien kontrakt zawierany między wyborcami i wybieranymi (Tyrała, 2018, s. 62). Programy polityczne cechuje charakter długoterminowy, w niewielkim stopniu odnoszą się one do bieżącej debaty politycznej (Yadav, 2014, s. 40). Stanowią one jakoby stadium pośrednie między doktryną polityczną a skonkretyzowanym działaniem politycznym (Antoszewski, Herbut, 2002, s. 76). Problematyka obecności w treściach programowych partii politycznych polityki bezpieczeństwa sensu largo (Indraszczyk, 2008, ss. 31-48; Płoski, 2005, ss. 65-70) czy jego poszczególnych wymiarów, jak społecznego (Tomaszewski, 2017, ss. 137-147), żywnościowego (Toszek, 2018, ss. 51-63) czy kulturowego (Lewandowski, 2016, s. 147159) była do tej pory często podejmowana w rozważaniach naukowych. Pomimo faktu, iż energetyczny aspekt kreowania bezpieczeństwa cieszy się nieustającym zainteresowaniem badaczy reprezentujących odmienne dyscypliny naukowe, niewystarczająca jest refleksja umiejscawiająca go w konkretnych programach politycznych. Bezpieczeństwo energetyczne stanowiąc główny cel prowadzonej przez państwo polityki energetycznej stanowi wyzwanie dla badaczy m.in. ze względu na istnienie różnych czynników je determinujących (Anokhin, Gsishin, 2013, s. 15). Problematyka bezpieczeństwa energetycznego stanowi również przedmiot rozważań w praktyce politycznej państw (Rosicki, Gielnik, 2014, s. 467). Jak wskazuje Organizacja Współpracy Gospodarczej i Rozwoju (OECD), bezpieczeństwo energetyczne jest, obok zmian klimatu, nadrzędnym celem realizowanej przez państwa polityki energetycznej (OECD, 2007, s. 3). Jak słusznie zauważyli Margarita Balmaceda i Andreas Heinrich pojęcie bezpieczeństwa energetycznego jako fundamentalny cel polityki energetycznej koncentruje się na takich problemach, jak zapewnienie ciągłości dostaw energii, przyczynach potencjalnych przerw w dostawach i ich skutkach geopolitycznych (Balmaceda, Heinrich, 2020, s. 481). Bezpieczeństwo energetyczne może być również rozumiane jako pojęcie przypominające swym kształtem parasol, obejmujący i łączący ze sobą wiele kwestii: energię, wzrost gospodarczy oraz politykę (Podraza, 2018, s. 47). Syntetyczną definicję bezpieczeństwa energetycznego przedstawił Erhard Cziomer określając, iż jest to dostępność energii w każdym czasie, w różnych formach, w wystarczającej ilości i po rozsądnej cenie (Cziomer, 2008, s. 18). W podobnym tonie pisze Marek Rewizorski - „bez- 
pieczeństwo energetyczne można utożsamiać z bezpieczeństwem dostaw, czyli zabezpieczeniem fizycznych i nieprzerwanych dostaw «energii» dla społeczeństwa i gospodarki, przy założeniu, że ceny jej będą dostępne dla wszystkich konsumentów" (Rewizorski, 2015, s. 262; Rosicki, 2018, s. 231).

Bezpieczeństwo energetyczne oparte jest również na trzech filarach: ciągłości dostaw energii po optymalnych kosztach, zachowaniu niezależności politycznej oraz oparciu dostaw energii na zasadach zrównoważonego rozwoju (Gradziuk, Lach, Posel-Częścik, Sochacka, 2002, s. 708). Na gruncie krajowego prawodawstwa bezpieczeństwo energetyczne definiowane jest jako stan gospodarki umożliwiający pokrycie bieżącego i perspektywicznego zapotrzebowania odbiorców na paliwa i energię w sposób technicznie i ekonomicznie uzasadniony, przy zachowaniu wymagań ochrony środowiska (Ustawa, 1997, art. 3, pkt 16). Bezpieczeństwo energetyczne należy więc rozpatrywać interdyscyplinarnie, w wymiarach: politycznym, gospodarczym, technologicznym oraz prawnym (Kwiatkiewicz, 2014, s. 23).

\section{Prawo i Sprawiedliwość - w kierunku suwerenności energetycznej}

Bezpieczeństwo państwa stało się istotnym elementem programu Prawa i Sprawiedliwości „Polski model państwa dobrobytu”. Dokument ten, liczący 229 stron, w wielu miejscach porusza omawianą w niniejszym artykule problematykę. Po raz pierwszy kluczowa rola bezpieczeństwa w wymiarze energetycznym została zaprezentowana już na 35 stronie badanego dokumentu i określona jako trzeci filar naprawy państwa (Prawo i Sprawiedliwość, 2019, s. 35). Szczegółowe omówienie bezpieczeństwa energetycznego zaczyna się od 96 strony programu. Przedstawiono w tym fragmencie koncepcję suwerenności energetycznej Polski. Składa się ona $\mathrm{z}$ dwóch zasadniczych filarów inwestycji w infrastrukturę przesyłową oraz wewnętrznych zmian organizacyjnych. Do pierwszej dziedziny zaliczono realizację projektu gazociągu Baltic Pipe, łączącego Polskę z Danią i Norwegią oraz dalszą rozbudowę gazoportu im. Prezydenta Lecha Kaczyńskiego w Świnoujściu (Prawo i Sprawiedliwość, 2019, s. 96). Dodatkowo postulowano zwiększenie współpracy ze Stanami Zjednoczonymi w kontekście importu skroplonego gazu ziemnego (Prawo i Sprawiedliwość, 2019, s. 189). Wewnętrzny wymiar suweren- 
ności energetycznej to z kolei powstanie jednego koncernu paliwowego będącego wynikiem fuzji Orlenu oraz Lotosu. Zdaniem autorów przełoży się to w okresie średnioterminowym na korzystniejszą cenę przy zakupie ropy i w konsekwencji skutkować będzie utrzymaniem cen na stabilnym poziomie (Prawo i Sprawiedliwość, 2019, s. 97). Rozwinięciem koncepcji suwerenności energetycznej jest też planowana inwestycja w budowę elektrowni jądrowych, które do 2035 roku mają zapewnić ok. 10\% energii elektrycznej wytwarzanej w kraju oraz 20\% w latach 2040-2043. Autorzy programu wyraźnie wskazują na fundamentalną rolę węgla jako surowca gwarantującego bezpieczeństwo Polski w omawianym aspekcie (Prawo i Sprawiedliwość, 2019, s. 84). Wyraźnie zaakcentowano w tej kwestii konieczność wdrożenia przygotowanych norm jakościowych węgla oraz zwiększania zakresu technologii innowacyjnych w tej sferze gospodarki (Prawo i Sprawiedliwość, 2019, s. 97). Rozwój bezpieczeństwa Polski w wymiarze odnawialnych źródeł energii ma być oparty z kolei na pozyskiwaniu energii fotowoltaicznej, wiatrowej i biogazowej. Jako ułatwienie w tym zakresie przedstawiono konkretne programy - „Czyste powietrze” oraz „Mój prąd”. Skoncentrowane są one przede wszystkim na gospodarstwach domowych, a ich celem jest redukcja szkodliwych dla środowiska pyłów oraz ograniczenie emisji $\mathrm{CO}_{2}$ (Prawo i Sprawiedliwość, 2019, s. 166).

\section{Koalicja Obywatelska - energia przyjazna środowisku}

Program Koalicji Obywatelskiej „Twoja Polska” zawarty został na 136 stronach. Problematyka energetyczna ujęta została po raz pierwszy na stronie 92, w części poświęconej zagadnieniu czystego powietrza. Autorzy programu, w przeciwieństwie do podejścia Prawa i Sprawiedliwości, akcentują stopniową eliminację węgla jako podstawowego surowca energetycznego. Zdaniem przedstawicieli Koalicji Obywatelskiej powinno to nastąpić stopniowo - do 2030 roku w ogrzewaniu domów i mieszkań, do 2035 roku w ogrzewaniu systemowym, a do 2040 roku w całej energetyce. Powstałą po odejściu od węgla lukę wypełnić mają instalacje z wykorzystaniem ogniw fotowoltaicznych oraz farm wiatrowych (Koalicja Obywatelska, 2019, s. 92). Autorzy dokumentu niezbyt wyraźnie wyjaśnili co w takiej sytuacji zrobić z pracującymi w kopalniach czy elektrowniach węglowych. W dalszej części programu zwrócono również uwagę na znaczną wartość importu węgla z Federacji Rosyjskiej, co 
w zestawieniu z opisanym przez autorów brakiem wyraźnej i koherentnej strategii energetycznej nie przyczynia się do poprawy omawianego wymiaru bezpieczeństwa państwa (Koalicja Obywatelska, 2019, s. 96). Rozwiązania dotyczące transformacji polskiej energii w kierunku zwiększenia udziału źródeł odnawialnych, w zestawieniu z propozycją Prawa i Sprawiedliwości, są bezsprzecznie częściej akcentowane w programie Koalicji Obywatelskiej. Proponowane rozwiązanie koncentruje się na promowaniu inwestycji w tzw. zieloną energię, która do 2030 roku, zdaniem autorów programu, powinna pochodzić ze źródeł odnawialnych: wiatru, słońca oraz wody. Gospodarstwa rodzinne, samorządy czy firmy, które zdecydują się na instalacje umożliwiające wykorzystanie źródeł odnawialnych mają być dofinansowywane przez państwo. Interesującym rozwiązaniem było zaproponowanie możliwości oddawania do lokalnych sieci nadwyżek pozyskanej energii (Koalicja Obywatelska, 2019, s. 101). Deklarowana wartość, którą miano osiągnąć do 2030 roku to $10 \mathrm{GW}$ energetyki słonecznej, $10 \mathrm{GW}$ energetyki morskiej i $10 \mathrm{GW}$ pozyskane z elektrowni wiatrowych (Koalicja Obywatelska, 2019, s. 98-99). W zewnętrznym wymiarze zapewnienia omawianego bezpieczeństwa podkreślono istotę dywersyfikacji dostaw energii z różnych źródeł oraz wkład w tzw. solidarność energetyczną w ramach Unii Europejskiej (Koalicja Obywatelska, 2019, s. 103).

\section{Komitet Wyborczy Sojusz Lewicy Demokratycznej (Lewica) - koniec dominującej pozycji węgla}

Lewica w swym programie „Polska jutra”, który liczył tylko 19 stron, w niewielkim stopniu i szczegółach porusza problematykę energetycznego aspektu bezpieczeństwa Polski. Nie jest to wyraźnie najważniejszy sektor z punktu widzenia polityków tworzących tę koalicję (BiznesAlert, 2019). Już w pierwszym punkcie programu Lewicy wskazana jest droga reform polskiego sektora energetycznego. Autorzy postulują zredukowanie zużycia paliw kopalnych w energetyce na rzecz czystych źródeł energii. W dłuższej perspektywie czasowej miało to skutkować zakazem importu węgla i zwiększeniem do 2035 roku udziału energii pozyskanej ze źródeł odnawialnych (Lewica, 2019, s. 3). Lewica w swoim programie zapowiadała również dofinansowywanie wymiany pieców węglowych na bezemisyjne instalacje - proces wymiany miałby potrwać 15 lat. 


\section{Polskie Stronnictwo Ludowe. Koalicja Polska - większa rola odnawialnych źródeł energii w miksie energetycznym}

Ujęty na 28 stronach program Polskiego Stronnictwa Ludowego Koalicja Polska, w kontekście kreowania polityki energetycznej wpisuje się w tendencje stopniowego odchodzenia od węgla na rzecz odnawialnych źródeł energii. Autorzy dokumentu postulowali zwiększenie tych ostatnich do $50 \%$, do 2030 roku. Dodatkową zachętą miało być obniżenie stawki VAT do $8 \%$ na rozwiązania oparte na tej technologii (Polskie Stronnictwo Ludowe. Koalicja Polska, 2019, s. 17). Kolejną propozycją było także cofnięcie tzw. „ustawy wiatrakowej” przy jednoczesnej zgodzie społeczności lokalnej. Ustawa ta, przyjęta w 2016 roku stanowi, iż odległość między elektrownią wiatrową a budynkiem mieszkalnym lub od formy ochrony przyrody winna być równa lub większa od dziesięciokrotności wysokości elektrowni wiatrowej mierzonej od poziomu gruntu do najwyższego punktu budowli, wliczając elementy techniczne, w szczególności wirnik wraz z łopatami (Ustawa, 2016, art. 4). W analizowanym programie Polskie Stronnictwo Ludowe nie wskazało jednak w oparciu o jak przeprowadzone konsultacje miałoby wyglądać uzyskanie owej zgody mieszkańców (Polskie Stronnictwo Ludowe. Koalicja Polska, 2019, s. 17). Swoista nieścisłość dotyczy proponowanego embarga na węgiel importowany z Federacji Rosyjskiej (Polskie Stronnictwo Ludowe. Koalicja Polska, 2019, s. 24). Zgodnie bowiem z regulacjami przyjętymi przez Światową Organizację Handlu, której członkami jest Polska i Rosja, embargo byłoby nielegalne. Wiele akcentów w badanym programie politycznym dotyczyło odnawialnych źródeł energii. Ludowcy postulowali budowę budynków plus energicznych - wytwarzających więcej energii niż pobierających. Wskazywali ponadto na rolę paneli fotowoltaicznych, biogazowni oraz elektrowni wodnych (Polskie Stronnictwo Ludowe. Koalicja Polska, 2019, s. 18). Enigmatycznie zdefiniowany został jednak zapowiedziany w dokumencie system punktowy. Jego beneficjentami miały zostać gospodarstwa wdrażające przy wydawaniu zgody na budowę rozwiązań proekologicznych (np. pokrycia dachu instalacją fotowoltaiczną).

\section{Konfederacja Wolność i Niepodległość \\ - między węglem a zieloną energią}

Zapewnienie bezpieczeństwa Polski było jednym z elementów tzw. piątki programowej Konfederacji. W interesującym autora niniejszego 
artykułu aspekcie wizji polityki energetycznej proponowane rozwiązania nie zostały jednak obszernie uwzględnione. Konfederacja niejako w kontrze do energetycznej polityki Unii Europejskiej zauważa potencjał drzemiący w energii jądrowej (Konfederacja Wolność i Niepodległość, 2019, s. 14). W kontekście dyskusji nad przyszłością polskiego sektora energetycznego opartego na wydobyciu węgla Konfederacja nie wypowiada się jednoznacznie. $Z$ jednej strony zaakcentowana została konieczność promocji czystych technologii, z drugiej jednak autorzy podkreślili, iż nie są przeciwnikami produkcji energii z węgla (Konfederacja Wolność i Niepodległość, 2019, s. 18). Wyraźnie uwypuklone zostało stanowisko autorów programu dotyczące pakietu klimatycznego Unii Europejskiej, który winien zostać wypowiedziany (Konfederacja Wolność i Niepodległość, 2019, s. 18-19). Trzema najważniejszymi celami pakietu klimatyczno-energetycznego jest ograniczenie o $20 \%$ emisji gazów cieplarnianych, 20\% udział energii pozyskiwanej ze źródeł odnawialnych oraz zwiększenie w takim samym wymiarze efektywności energetycznej.

\section{Podsumowanie}

Bezpieczeństwo energetyczne stanowi niezmiernie ważną gałąź bezpieczeństwa zarówno w wymiarze narodowym, jak i międzynarodowym. Istotna rola omawianego aspektu bezpieczeństwa znalazła odzwierciedlenie w Strategii Bezpieczeństwa Rzeczpospolitej z 2020 roku. Wymiar ten został wręcz określony jako kluczowy dla bezpieczeństwa Polski (Biuro Bezpieczeństwa Narodowego, 2020, s. 8). Osiągnięcie wymaganego poziomu bezpieczeństwa energetycznego wymaga prowadzenia innowacyjnej polityki opartej na solidarnej współpracy między państwami. Prezydent Rzeczpospolitej, Andrzej Duda, stwierdził, iż „Zaczynamy budowę Baltic Pipe, a więc gazociągu, który ma prowadzić gaz z szelfu norweskiego, poprzez Danię, po dnie Morza Bałtyckiego do Polski. To są wielkie inwestycje, które mają nam gwarantować bezpieczeństwo, także suwerenność gazową - przede wszystkim uniezależnienie się od dostaw z Rosji” (polskieradio24.pl, 2020). Dążenia te wspiera Unia Europejska. W październiku 2020 roku prawie $720 \mathrm{mln}$ euro zostało przeznaczone na projekty umożliwiające synchronizację sieci energetycznych państw bałtyckich z systemem kontynentalnym. Z tej kwoty blisko 500 mln euro zostało zarezerwowane na budowę podmorskiego kabla łączącego Polskę z Litwą „Harmony Link” (cire.pl, 2020). Z przeprowadzonej w niniej- 
szym artykule analizy wynika, iż rolę bezpieczeństwa energetycznego jako głównego celu polityki energetycznej państwa dostrzegły wszystkie najważniejsze polskie partie polityczne. Główne różnice dotyczyły charakteru polskiego miksu energetycznego. Jedynie Prawo i Sprawiedliwość wyraźnie opowiadało się na dominacji węgla, jako podstawowego surowca energetycznego. Pozostałe ugrupowania akcentowały w swoich programach konieczność odejścia od tego nieodnawialnego surowca na rzecz odnawialnych źródeł energii. W pewien sposób po środku tej osi sporu znalazła się Konfederacja Wolność i Niepodległość, która niejednoznacznie określiła się w tej kwestii, z jednej strony akcentując strategiczną rolę węgla, z drugiej technologie czystej energii. Jest to być może egzemplifikacja koncentracji na aspektach uznanych za najistotniejsze (sprzeciw wobec energetycznej i klimatycznej polityki Unii Europejskiej) przede wszystkim przez samo ugrupowanie aniżeli jego wyborców. Znaczenie bezpieczeństwa energetycznego Polski było również akcentowane w kontekście importu węgla z Federacji Rosyjskiej. W tym względzie dominujące akcenty koncentrowały się na zwiększaniu dywersyfikacji dostaw energii z innych źródeł, np. poprzez inwestycję Baltic Pipe oraz na konieczności rezygnacji z dostaw rosyjskiego węgla. Ten ostatni postulat wydaje się nierealny z ekonomicznego punktu widzenia. Węgiel wydobywany w Rosji jest znacznie tańszy (podobnie zresztą jak australijski). Składa się na to szereg czynników m.in. - tańsza siła robocza oraz znacznie niższe normy bezpieczeństwa, zarówno górników, jak i środowiska naturalnego. Spośród największych trudności w zapewnieniu Polsce bezpieczeństwa energetycznego omawiane partie polityczne najczęściej wskazywały dominującą pozycję Federacji Rosyjskiej w regionie i ryzyko płynące z niewystarczającej dywersyfikacji złóż dostaw energii. Akcentowane było również zaprzestanie importu tańszego węgla z Rosji. Niestety oprócz nośnego hasła nie zaproponowano w tej kwestii konkretnych rozwiązań. Należy podkreślić, iż rosyjski węgiel cechuje również znacznie mniejszy poziom zasiarczenia aniżeli jego odpowiednika wydobywanego w Polsce. Bezpieczeństwo energetyczne Polski jest bardzo ściśle powiązane z priorytetami Unii Europejskiej, dla której kluczowymi obszarami pozostaje: dywersyfikacja paliw, źródeł dostaw oraz szlaków tranzytowych. Państwa Unii pozostają silnie uzależnione od importu surowców energetycznych z Federacji Rosyjskiej, dla której swoista gra energią pozostaje przedłużeniem dyplomacji oraz narzędziem wpływu politycznego (Rosicki, 2010, s. 114). Obecnie to węgiel jest podstawowym surowcem tzw. miksu energetycznego Polski. Jak szacują dane, odpowiada za mniej 
więcej 80 procent produkcji energii. Programy polityczne analizowanych partii nie wskazują jednak gotowej odpowiedzi w jaki sposób w ciągu najbliższych trzydziestu lat zapewnić energię niepochodzącą z węgla? Niezmiernie pozytywnie ocenić należy poruszanie w programach kwestii odnawialnych źródeł energii, jako przyszłego kierunku wzmacniającego energetyczny poziom bezpieczeństwa Polski. Proponowane rozwiązania, choć słuszne, nie doczekały się jednak bardziej skonkretyzowanych wyjaśnień. Szczególny brak, który jest obserwowany we wszystkich badanych programach wyborczych to oferta wychodząca naprzeciw pytaniu w jaki sposób zachęcić Polaków do inwestowania w odnawialne źródła energii? Bezpieczeństwo, jak słusznie zauważa Joanna Rak jest dobrem publicznym, które wymaga ochrony (Rak, 2018, s. 28). Konstatacja ta dotyczy również jego wymiaru energetycznego. Konieczne jest wypracowanie ponadpartyjnego konsensusu uwzględniającego polską rację stanu w perspektywie długofalowej. Dyskusja nad kształtem polskiej energetyki winna wyjść poza okowy partykularnych interesów poszczególnych partii i uwzględnić stanowisko ekspertów czy opinii publicznej.

\section{Bibliografia}

Anokhin M., Grishin O. (2013), Energy safety: politics and diplomacy, „Przegląd Strategiczny", nr 1.

Antoszewski A., Herbut R. (2002), Leksykon politologii, Atla 2, Wrocław.

Balmaceda M., Heinrich A. (2020), The Energy Politics of Russia and Eurasia, w: The Oxford Handbook of Energy Politics, red. K. J. Hancock, J. E. Allison, Oxford University Press, New York.

Biuro Bezpieczeństwa Narodowego (2020), Strategia Bezpieczeństwa Narodowego Rzeczpospolitej, Warszawa.

BiznesAlert (2019), Energetyka na wyborach parlamentarnych. Co proponuja partie?, 11.10.2019, https://biznesalert.pl/programy-partii-energetyka-wybory-2019/, 18.02.2021.

Budge I., Robertson D., Hearl D. (1987), Ideology, strategy and party change: spatial analyses of post-war election programmes in 19 democracies, Cambridge University Press, Cambridge.

Cire.pl. (2020), Prawie $720 \mathrm{mln}$ euro dofinansowania z CEF na synchronizacje państw baltyckich, https://www.cire.pl/item,205241,1,0,0,0,0,0,prawie-720-mln-euro-dofinansowania-z-cef-na-synchronizacje-panstw-baltyckich. html, 7.01.2020.

Cziomer E. (2008), Międzynarodowe bezpieczeństwo energetyczne w XXI wieku, Krakowska Szkoła Wyższa im. Andrzeja Frycza Modrzewskiego, Kraków. 
Gradziuk A., Lach W., Posel-Częścik E., Sochacka K. (2002), Co to jest bezpieczeństwo energetyczne państwa?, „Biuletyn PISM”, nr 103.

Indraszczyk A. (2008), Problem bezpieczeństwa państwowego i międzynarodowego w programach polskich partii politycznych, „Doctrina, Studia społeczno-polityczne", vol. 5, ss. 31-48.

Koalicja Obywatelska (2019), Twoja Polska, Warszawa.

Kolanko M. (2019), Sondaż: Jakie tematy interesuja Polaków przed wyborami?, 19.08.2019, „Rzeczpospolita”, https://www.rp.pl/Wybory-parlamentarne-2019/308189967-Sondaz-Jakie-tematy-interesuja-Polakow-przed-wyborami.html, 18.02.2021.

Komitet Wyborczy Sojusz Lewicy Demokratycznej (Lewica) (2019), Polska jutra, Warszawa.

Konfederacja Wolność i Niepodległość (2019), Polska dla Ciebie, Warszawa.

Kwiatkiewicz P. (2014), Bezpieczeństwo energetyczne. Rynki surowców i energii-teraźniejszość i przyszłość, t. 2, Fundacja na rzecz Czystej Energii, Poznań.

Lewandowski A. (2016), Bezpieczeństwo kulturowe jako przestrzeń sporu politycznego pomiędzy Prawem i Sprawiedliwościa a Platforma Obywatelska. Analiza programów wyborczych, w: Człowiek wobec współczesnych wyzwań kulturowych, pod red. E. Chojnacha, J. Michalskiego, Wydawnictwo Naukowe Państwowej Wyższej Szkoły Zawodowej w Płocku, Płock, s. 147-159.

OECD (2007), Energy Security and Climate Change - Assesing Interactions, International Energy Agency, Michigan.

Państwowa Komisja Wyborcza (2019), Wyniki wyborów 2019 do Sejmu RP, https:// sejmsenat2019.pkw.gov.pl/sejmsenat2019/pl/wyniki/sejm/pl, 4.01.2021.

Podraza A. (2018), Problemy i zagrożenia a rozwój koncepcji bezpieczeństwa energetycznego, w: Bezpieczeństwo energetyczne. Koncepcje, wyzwania, interesy, red. J. Gryz, A. Podraza, M. Ruszel, PWN, Warszawa.

PolskieRadio24. (2020), Prezydent: inwestycje $w$ energetyce zagwarantuja nam bezpieczeństwo, https://www.polskieradio24.pl/42/273/Artykul/2508821, Prezydent-inwestycje-w-energetyce-zagwarantuja-nam-bezpieczenstwo, 8.01.2020.

Polskie Stronnictwo Ludowe. Koalicja Polska (2019), Łączymy Polaków, Warszawa.

Płoski M. (2005), Bezpieczeństwo narodowe a programy partii politycznych, w: Bezpieczeństwo narodowe a grupy dyspozycyjne, pod red. J. Maciejewskiego, O. Nowaczyk, Wyd. Uniwersytetu Wrocławskiego, Wrocław, ss. 65-70.

Prawo i Sprawiedliwość (2019), Polski model państwa dobrobytu, Warszawa.

Rak J. (2018), Theorizing Cultures of Political Violence in Times of Austerity: Studying Social Movements in Comparative Perspective, Routledge, London-New York.

Rewizorski M. (2015), Z powrotem do debaty neo-neo. Dwa spojrzenia na bezpieczeństwo energetyczne, „Przegląd Strategiczny”, nr 8.

Rosicki R. (2010), Chiny i Indie a bezpieczeństwo energetyczne Europy, „Przegląd Bezpieczeństwa Wewnętrznego", nr 2. 
Rosicki R., Gielnik A. (2014), Bezpieczeństwo energetyczne i ekologiczne na przykładzie węgla brunatnego w Polsce, w: Bezpieczeństwo energetyczne. Rynki surowców i energii - teraźniejszość i przyszłość, t. II: Geopolityka - Polska - Świat, red. P. Kwiatkiewicz, Fundacja na Rzecz Czystej Energii, Poznań.

Rosicki R. (2018), Kultury energetyczne Unii Europejskiej, Wydawnictwo Naukowe Wydziału Nauk Politycznych i Dziennikarstwa UAM w Poznaniu, Poznań.

The Warsaw Institute Review (2019), Nowe otwarcie $w$ polityce energetycznej $i$ bezpieczeństwa energetycznego $w$ Polsce po wyborach parlamentarnych 2019 roku, https://warsawinstitute.review/pl/numer-4-2019/nowe-otwarciew-polityce-energetycznej-i-bezpieczenstwa-energetycznego-w-polsce-powyborach-parlamentarnych-2019-roku/, 1.01.2021.

Tomaszewski P. (2017), Bezpieczeństwo społeczności lokalnych $w$ dokumentach programowych wybranych partii startujacych $w$ wyborach parlamentarnych 2015 roku, „Atheneum. Polskie Studia Politologiczne”, vol. 54, ss. 137-147.

Toszek B. H. (2018), Kwestia bezpieczeństwa żywnościowego w programach największych partii i ugrupowań politycznych $w$ wyborach parlamentarnych $w 2015$ roku, w: Partie i ugrupowania polityczne wobec polityki bezpieczeństwa Polski w XXI wieku. Założenia i realizacja wybranych programów politycznych, pod red. M. Kamoli-Cieślik, Ł. Tomczaka, wyd. Uniwersytetu Szczecińskiego, Szczecin, ss. 51-63.

Tyrała M. (2018), Wpływ postulatów programowych na sukces wyborczy - na przykładzie partii: PiS, PO, ZL w wyborach parlamentarnych $w$ Polsce $w 2015$ roku, „Środkowoeuropejskie Studia Polityczne”, nr 1.

Ustawa (1997), Prawo energetyczne, Dz. U. 1997, Nr 54, poz. 348.

Ustawa (2016), O inwestycjach w zakresie elektrowni wiatrowych, Dz. U. 2016, poz. 961.

Woźniak W. (2017), Programy polskich partii politycznych jako materiat empiryczny w badaniach dyskursu politycznego, „Środkowoeuropejskie Studia Polityczne", $\mathrm{nr} 2$.

Yadaw S. (2014), Political parties management, Lulu.com, Morrisville.

\section{The issue of raw material security in the programs of the largest Polish political parties in the parliamentary elections in 2019}

\section{Summary}

The subject of this article is the vision for energy policy in the political programs of the largest Polish political parties in 2019. It should be emphasized that energy policy's main goal is to ensure energy security. The aim of the research undertaken by the author is to identify, discuss and compare the concepts for ensuring Poland's energy security in the event of various parties winning the parliamentary elections. The following research problems were used to achieve the research objectives defined 
in this way: to what extent is Poland's energy security present in the analyzed political programs? Through what tools have the largest political parties in Poland created the energy dimension of security? What are the main difficulties in ensuring Poland's energy security highlighted by the political parties studied? Is there a convergence of political parties in the vision of guaranteeing Poland's energy security? The following research methods were used in the article: comparative and source analysis. The content analysis technique was also used.

Key words: security; energetic security; political programs; political parties 
